\title{
The Development of Islāmic Culture and Civilization in Kashmīr and the Contribution of Muslim Süfiss during the Medieval Times
}

\author{
*Tajamul Ahmad Sheikh
}

Doctoral Candidate, Shah-i Hamadan Institute of Islamic Studies, Faculty of Social Science, University of Kashmir, Srinagar, India

\begin{abstract}
Kashmir has a long unique structure and identity due to its geographical beauty, natural resources, and traditional spiritual ethos since antiquity. In ancient times, although most Kashmiris were followers of Buddhism and Hinduism, in addition to these traditional religions, there was also an influential group ascetic mystics called Rishis in Kashmir. They devoted their entire lives to abstinence (Nafs Kashi) and various spiritual struggles in order to control their desires of carnal self (Mujäida's). From the beginning of medieval times which is known as the golden age of Islamic civilization and culture, the message of Islam spread rapidly throughout the world. In this regard, the group of Șifis played vital role in the whole Islamic world. In Kashmir, as in the rest of the subcontinent, Șüis made significant contributions to the propagation of Islam. The present article will examine the historical events of the medieval times, which are considered a milestone in the spread of Islam and the promotion of Islamic civilization in Kashmir. Moreover, the works of those Süfi masters will be reviewed who have sacrificed a lot and done commendable works on the history of Kashmir.
\end{abstract}

Keywords: Kashmir, Buddhism, Hinduism, Șüfīs, Islamic

\section{$\underline{\text { Article Publication }}$}

Published Online: 15-Dec-2021

*Author's Correspondence

8 Tajamul Ahmad Sheikh

8 Doctoral Candidate, Shah-i Hamadan Institute of Islamic Studies, Faculty of Social Science, University of Kashmir, Srinagar, India

$\triangle$

tajamuls.scholar[at]kashmiruniversity.net

(C) 2021The Authors. Published by RESEARCH REVIEW International Journal of Multidisciplinary. This is an open access article under the CC BY-

NC-ND license ${ }_{\text {BY NG ND }}$

(https://creativecommons.org/licenses/ by-nc-nd/4.0/)

\section{Introduction}

The Kashmir ${ }^{1}$ valley known worldwide for its natural scenery and beauty, is also famous for its cultural and spiritual traditions from ancient times. Since medieval age the region has been the abode of religious scholars, Șüfis, religious preachers, due to which it is known as "pirwari." 2 In the Medieval times, a large group of Șüfis from Irān and Turkestān spread Islām in the Kashmīr Valley. They dedicated their lives here by presenting theoretical and practical examples of Islāmic teachings, and the people of Kashmìr got impressed to see the same. The history of Kashmir bears witnesses to the fact that the Siffis were the most prominent contributors to the promotion of Islāmic culture in Kashmìr, and it was through them that Islāmic civilization and culture flourished in Kashmīr. It is a historical fact that the rays of Islāmic light in Kashmīr are spread through Süfiss. However, Islāmic influences began to flourish in Kashmìr valley as early as 711-13 AD, but Islām began to prosper in the early fourteenth century AD in this region with its beauty and elegance. Thus, the first Muslim government was started in Kashmir valley, and due to the civilization and culture of the Muslims, the people of this region became very bright and exemplary.

\section{The First Impressions of Islām in Kashmīr}

In ancient times, Kashmir, like the rest of the subcontinent, had an abundant number of followers of both Hinduism and Buddhism. Hinduism was at its peak in Kashmir when the propagation of Islam in seventh century

\footnotetext{
${ }^{1}$ Kashmìr, claimed by both India and Pakistan, is a part of the Indian subcontinent's north western corner.

2 "Pirwari" in Kashmìri language means the valley of holy saints.
} 
CE began to spread outside the Arab world. The political, social, and religious control of Kashmir was also in the hands of the proponents of Hinduism. Hindus have owned the region for almost four thousand years, and almost twenty-one families of other Hindus have ruled the state in particular, and it is only because of this supremacy and dominance of these Hindu kings in the state their people, i.e., Kashmìri Brahmins and other nations continued to live a comfortable and prosperous life in those days. Therefore, with time, the policy of the Hindus did not succeed for a long time. With the changing times, the conditions of the country also began to change. The growing power and rise of Muslim countries forced the Hindus to establish relations with the Muslim majority countries and then reconsidered the strategy adopted by the Hindus in this regard and lifted all restrictions on the entry of Muslims into their country. ${ }^{3}$

For Kashmīri historians, the question of propagation of Islām and its consolidation in Kashmīr has been a matter of debate since times immemorial. However, most historians agree that the first wave of Islām in Kashmir started from the Hindu era. ${ }^{4}$ When Islām spread with full force in the Kashmīr region, the mighty armies of Islāmic thought, literature, science, culture, and civilization also rose from the different parts of the subcontinent and began to enter the Kashmīr valley. Dr. Farūq Bukhārī, in his book "Kashmìr mein Isläm Manz̧ar aur Pas-e-Manz̧ar," while describing the historical development of Islām in Kashmīr states that The presence of Islāmic influences in Kashmīr is found in ancient times, when Muhammad bin al-Qāsim's ${ }^{5}$ contemporary ruler Lalitāditya's ${ }^{6}$ successor Vajraditya, ${ }^{7}$ according to Kalhana, ${ }^{8}$ introduced many [Islāmic] traditional customs/practices of the Muslim community (called malecchas) in his country (Kashmir) and also sold many Kashmiri men to the Arab Muslims (malecchas) [of Sindh] which continued for a longer time. Even in the last decade of the eleventh century CE, Raja Harsh Dev,9 inspired by Islām, embarked on a vigorous religious reform campaign in Kashmīr. He did not hesitate to sacrifice his own life in this way. ${ }^{10}$

From the very beginning of Medieval times, the golden age of Islāmic civilization and culture began. In the same period, the message of Islām spread all over the world at a rapid pace, and in this regard, the contribution of the Süfis is considered phenomenal throughout the Muslim world during the medieval times. Thus, from the eleventh century AD onwards, when the separate Süfi orders (silsilahs) began to establish in tasawwnf (Sufism), the idea of mystic hospices (khänqās) came into view as a result abundant number of these hospices (khänqās) began to be built for the stay and training of Süfis. These monasteries (kbānquass), besides providing practical spiritual training to the Sîfiss, also trained them to serve common people and impart spiritual light in them. As the number of seekers of truth increased with time, the Sïfis left their areas and migrated to different areas for the service of people, travelled only for the knowledge of the truth and especially for the propagation of Islām. They aroused the spirit of purification among people. As a result, innumerable people in every region, influenced by the character of these Süfiss, converted to Islām without any compulsion or violence. This way, Islām continuously spread throughout the world through the immense sacrifices of these Süfis, these services of them are not only acknowledged but also historically overviewed by the famous orientalist T.W. Arnold in his book "The Preacbing of Isläm."11

\footnotetext{
${ }^{3}$ Syyed 'Alī Raza, Wadi Kashmir k. Thazibi wa Saqafati hamajahati peblu, unpublished thesis submitted to Punjab University, Lahore, 2008, page no. 9 .

${ }^{4}$ Khan, Professor Mohammad Ishaq, Kashmir's Transition to Islam: Role of Rishis, Gulshan publishers, Srinagar, 2005.

${ }^{5}$ Muhammad bin al-Qāsim was an Arab General of the Umayyad Caliphate who successfully invaded and conquered Sindh and Multan by defeating the last Hindu ruler, Rājā Dāhir in the conquest of Aror. He was the first Muslim to conquer Hindu lands and establish the early Islāmic India in $712 \mathrm{CE} / 92 \mathrm{AH}$

${ }^{6}$ Lalitāditya Muktāpịda (ruled c. 724 CE-760 CE) was a powerful ruler of the Karkota dynasty in the Indian subcontinent's Kashmīr region.

7 Vajraditya was the youngest son of Kashmīi ruler L"Alītāditya, who ruled from 762 CE till 770 CE.

${ }^{8}$ Kalhana was one of the great historians of Kashmīr who wrote Räjatarangin̄i (River of Kings), an account of the Kashmīri History in Sanskrit.

${ }^{9}$ Harsh Dev (ruled 1089 CE-1111CE) was a Hindu king of Kashmīr India.

${ }_{10}$ Bukhari, Dr Syed Muhammad Farūq, Kashmir mein Islam: Manzar aur Pasi Manzar, Maktab ilm wa Adab Srinagar, Kashmīr, n.d., p. 49. Same fact has been mentioned by A.Q. Rafiqi, Sufism in Kashmir: Fourteenth to the Sixteenth Century, Good Media, Sydney, 2003 , p. 1.

11 Arnold, T.W., The Preaching of Islam: A History of the Propagation of the Muslim Faith, Constable \& Company Ltd., London, 1913, pp. $220-221$.
} 
The spread of Islām in Kashmīr was nurtured by these Süfiss. Thus, the imprint of Islām in Kashmìr can be traced back to the Ninth century CE, but the process of spreading Islām at the grassroots level in Kashmìr began with the arrival of Central Asian Ș üfis in Kashmir.. ${ }^{12}$ This process started from Hadrat Syed Sharaf-ud-Din Shurawardi aka Bulbul Shāh (رحمة الله عليه) and continued for centuries, with time not only became more effective, but this process of propagation of Islām became a permanent part of Kashmīrs' individual and collective identity. Therefore, as mentioned earlier, there was a group of abstinent and God-seeking people in Kashmir from antiquity who were looked upon with great reverence by people of Kashmir, so it would not be wrong to say that the people of Kashmir were already inclined towards spirituality due to which they got easily impressed by the teachings S Sufis who came from Persia and Central Asia. The fourteenth century AD is a significant century for the spread of Islām in Kashmīr in general and the foundation of Islāmic civilization in Kashmīr in particular.

On the one hand, for the first time in this century, the Muslims established an independent empire in Kashmir, which proved to be a golden chapter in the history of Kashmīr. In addition, the spread of Islām in this century also began to spread very fast. Sultan Șadar-ud-Dīn, the first Muslim ruler in Kashmìr, whose real name was Rinchan Shāh, converted to Islām due to persuasion and efforts of Syed Bulbul Shāh's (رحمة اله عليه). Historians write that Rinchan Shāh was initially a follower of Buddhism but was interested in studying other religions, especially the Hindu religion and Islām. He consulted the relevant religious scholars of both religions in order to study about their philosophies. He once invited both of the Hindu and Muslim scholars from Kashmīr in his court to deliberate upon the teachings of their respective religions. Among those who had accepted his invitation was Ḥaḍrat Bulbul Shāh (رحمة الله عليه), whose unique style of speech, religious arguments impressed him to such an extent that he in no time took an oath of allegiance in the hands of Bulbul Shāh (رحمة اله عليه) and converted to Islām. ${ }^{15}$ After conversion of Sultān Sadur-ud-Dīn to Islām, the spread of Islām in Kashmīr was pretty smooth. However, very few mosques and hermitages were still built in Kashmīrìs political and cultural life. No extraordinary revolution took place except the establishment of Islām, nor was any immediate step taken at the government level connected with the spread of Islām, not either was it patronized. The society of Kashmìr was still dominated by Hindu civilization and culture, which was adopted not only by the people but also by those in power. However, the ideas of purity, simplicity, and equality of Islāmic teachings began to impress common masses, especially the lower-class Hindus.

The transformational progress in the propagation of Islām in Kashmīr took place during the reign of Sultān Qutubu'd-Dīn Shāh Mīrī16 when an organized caravan of Süfis from central Asia arrived in Kashmìr. The aim of this caravan was neither the acquisition of wealth nor political victories, but this caravan of lovers, full of divine love and the spirit of societal service, came only to enlighten the people of this land of Kashmir with the light of Islām. The leader of this caravan was a great Șüfì thinker, whose name was the Hạạrat Mir Sayyid 'Alī Hamadānī

\footnotetext{
12 Saifud Dīn Bayhaqi, Syed, Noori Irfān, Kirmānī Publications Rafiabaad, Kashmīr, 2011, p. 5.

13 Various theories have been proposed regarding Hadrat Syed Sharaf-ud-Din Suhurawardi's birth. Some schools of thought claim he was a saintly celebrity from Bukhara, while others believe he was from Samarqand. Others are of the view that he was from Turkestān or Central Asia. However, the majority of people believe he came from Turkestān, hence the name of the great friend of Allāh (سُبْحَانَهُ وَتَعَاَلَّ) has the tag 'Turkestanī' attached to it.

${ }^{14} \mathrm{Kashmīrī} \mathrm{writers} \mathrm{have} \mathrm{given} \mathrm{Hậ̣rat} \mathrm{Bulbul} \mathrm{Shāh} \mathrm{(رحمة} \mathrm{الله} \mathrm{عليه)} \mathrm{a} \mathrm{number} \mathrm{of} \mathrm{names} \mathrm{and} \mathrm{titles.} \mathrm{The} \mathrm{historian,} \mathrm{Jonaraj,} \mathrm{is} \mathrm{hesitant} \mathrm{to}$ mention the saint's name. According to the author of the "Baharistan-i-Shahi”, when the king or others inquired about his identity, the holy saint introduced himself as "Bulbul Qalandar" and declared himself a Muslim. In his "Tarikh-i-Kashmī", Muhammad Azam refers to him

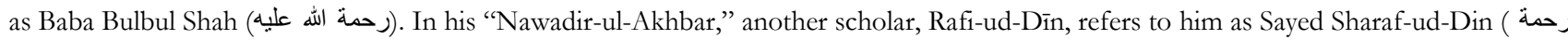
الله عليه . In his “Asrar-ul-Akbar,” Baba Dawūd Mishkātī refers to him as Ḥaḍrat Bābā Bilāl. In his book "Tarikh-i-Kashmīr,” Peer Ghulām Ḥassan Khuihamī states that his real name was Ḥaḍrat Sayed Sharaf-ud-Dīn (رحمة الله عليه). Some other scholars like G.M.D Ṣūfĩ calls him as Sharf-ud-Dīn Abdur Rahman Turkestānī (رحمة الله عليه).

${ }_{15}$ Musoodī, Muhammad, Rinchan say Ranjeet Tak, Book Media, Srinagar, n.d., p. 12.

16 The ruler of Kashmīr whose reign (r. 1373-89 CE) is remembered only for the arrival in Kashmīr of a Muslim traveller named Syed 'Ali Hamdani. Qutub'din died in 1380 CE, and his son Sultan Sikander, also known as Sikander Butshikand, took over as his successor.
} 
(رحمة الله عليه) (c. 1314 CE/713 AH-1384 CE/785 AH), ${ }^{17}$ who was well versed in religious (Shari’ah) sciences and was considered one of the leading Sufi mentor in the Kubrawiya order of taSamwuf(Sufism). ${ }^{18}$ Although the arrival of Süjisis in Kashmīir ${ }^{19}$ continued after Ḥaḍrat Bulbul Shāh (رحمة الله عليه) but still the majority of people in Kashmīr remained non-Muslims as no effective effort was made in this regard. With the arrival of Hadrat Mir Sayyid 'Ali Hamadānī (رحمة الله عليه) this vacuum of lack of da'wah20 in an organized way was filled. Haḍrat Mir Sayyid 'Alī

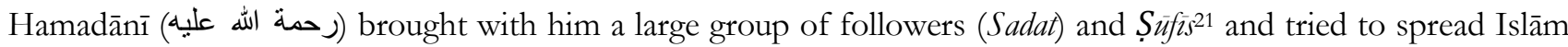
across the length and breadth of Kashmir. It is pertinent to mention here that the comrades that came along with Hua drat Mir Sayyid 'Alī Hamadānī (رحمة الله عليد) included Islāmic scholars and experts of diverse arts and crafts.22 Haḍrat Mir Sayyid 'Alī Hamadānī (رحمة الله عليه) not only brought religion of Islām with him, but he also brought with him the tools of complete culture and civilization. This endeavor of Haḍat Mir Sayyid 'Alī Hamadānī ( رحمة increased the social and intrinsic beauty of Kashmir along with its extrinsic beauty, resulting in social peace and harmony. The atmosphere of peace, both moral and spiritual, began to uplift with his enormous efforts. After Haḍrat Mir Sayyid 'Alī Hamadānī (رحمة الله عليه), the person who rendered historical services in the field of da'wah in Kashmīr is the patron saint of Kashmīr Valley, Sheikh Noor-ud-Dīn Noorānī (رحمة الله عليه).23 He prepared a large group of his followers and carried out the work of spreading Islām with great sincerity and devotion. ${ }^{24}$

\section{The Rise of Islamic Civilization in Medieval Kashmīr and the Services/Contributions of Sūfis}

Culture is such a broad term in which all aspects of society or ways of life come; that is, it is the name of all the thoughts and deeds of a nation's intellectual, emotional and spiritual life. When a nation sets its own style of development, it becomes its own culture. Therefore, culture is the name of the whole collection, including religion, beliefs, sciences and arts, ethics, habits, customs, and all the tendencies and affairs that man performs after acquisition. It is as if the concept of the term culture includes mental development, morals and etiquette, civilization, and national characteristics..$^{25}$

As already mentioned, the fourteenth century $\mathrm{AD}$ is a milestone in the history of Kashmir. Apart from an organized movement for the promotion of Islām, the promotion of Islāmic civilization also started in a very organized manner in the same century. It is pertinent to mention here that the same era has witnessed the immense religious services, sacrifices, and contributions from revered Șüfì saint Ḥaḍrat Mir Sayyid 'Alī Hamadānī

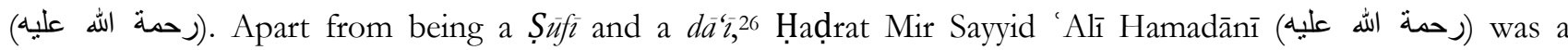
distinguished researcher and author. Historians are of the view that Ḥaḍrat Mir Sayyid 'Alī Hamadānī ( رحمة الله (عائ) (عليه authorized almost one hundred sixty works, among them most are written on the subject of the spirituality. Apart from them, many books have been written on various aspects of Islāmic civilization and culture. Haḍrat Mir Sayyid 'Alī Hamadānī's (رحمة الله عليه) prominent works include Zakbirat-ul-Muluk, Chahal Isrār (Fārsì Ghaž'Alìyät),

${ }^{17}$ Heḍrat Mir Sayyid 'Alī Hamadānī (رحمة الله عليه) was an eminent Sufi scholar and poet from Iran. He travelled across Central and South Asia and was instrumental in preaching Islam and practicing Sufism throughout his life. Reverentially Hadrat Mir Sayyid 'Alī Hamadānī was also as known King of Hamadan (“Shāh-e-Hamadān”), The Great Commander (“Amīr-i-Kabīr”) and Second 'Alī (“"Alī Thānì”). For further study about his remarkable contribution towards development of Islamic culture in Kashmir see, Dr Altaf Hussain Yatoo, Islamization of Kashmir, Gulshan Books, Srinagar, 2012, Shams-Ud-Din Ahmad, Shah-i-Hamadan: Hayat Aur Karnamay, Haji Sheikh Ghulam Muhammad And Sons ,1995, Syeda Ashraf Zaffar, Syed Mir Ali Hamadani, Sheikh Usman and Sons Srinagar, 2007.

18 Al-Ḥasan, Muhib, Kashmìr Salātin ke Aḥad mein, Urdu trns. Major 'Alī Ḥamād Abāsīi, Dārul Musannefīn Shiblī Academy, Azamgarh, Uttar Pradesh, 2010, p. 75.

19 The Süfis came and settled in different parts of Kashmīr only to enlighten people there with the teachings of Islām.

20 The act of inviting or calling people towards Islām.

${ }^{21}$ Most historians have written the number of these comrades as seven hundred.

${ }^{22} \mathrm{He}$ brought some carpet and shawl weavers with him, who taught the local community how to make pashmina textiles and carpets.

23 Also known as Nund Rishi and Alamdar-e-Kashmìr. He was among the founders of the Rishi order, a Süfí tradition of the Kashmīr region.

${ }^{24}$ Sofi, G.M.D., Islamic Culture in Kashmir, Capital Publishing House, Delhi, 1996, p. 40.

25 Durani, Aatsh, Islami Fikr wa Thaqafat, Maktaba 'Aliya, Lahore, 1980, p. 112.

${ }^{26} D \bar{a}^{a} \bar{\imath}$ is a Muslim who propagates the message of Islām and invites the people towards the same. 
Minhaj-ul-Ārifin, Mowadat-ul-Qurbā, Risälah Zakariyyā, Risälah Dah Qaida, Mirat ul-T'Alïbeen, Risälah Wajoodia, Risälab Hamadania, Risälah Eitiqadia, Masharibul Azwäq, Sharah Fasoosul Hikam, Munqabatul Jawahir, Asrarul Nuqt, Sharah Qasida-i-Khumria Fardia, Manazil-us-Sälikeen, Raudatul Firdous, Firdausul Akhyar, Koläșat al- manäqeb, Risälah Istilahat-iilm-ul-Qiyafah Arbayeen, Awrad-i-Fathia and many others. ${ }^{27}$ Referring to the selfless services and contributions of Haḍrat Mir Sayyid 'Alī Hamadānī (رحمة اله عليه). The revolutionary contribution of Sayyid Ali Hamadani and other Sädät [followers of Hamadani] in the spread of Islām in Kashmīr in such a short time that no other region of the subcontinent has such an example. This is the period in the history of Kashmir from which the construction of a new society began. The way of life, manners, language, culture, and the Kashmir nation's overall life took a new step and started a fresh life with great zeal and zest. Thus, the central Asian influences centered with a developing civilization have significantly been attached with the fertile soil as if they were actual inhabitants of here. It is as if the services of Hadrat Mir Sayyid 'Alī Hamadānī (رحمة الله عليه) had an impact not only on the rulers of Shāh Mīrī but also on the people, the scholars and especially the Șüfis of Kashmīr and Rishis.

With the spread of Islām, the Islāmic atmosphere in Kashmīr embellished its culture. As soon as Süfis entered here, they urged the Muslims to pursue education, which was earlier mostly confined to the Brahmins. Thus, the Hindu language of Sanskrit began to decline, and Persian and Arabic began to rise. At the same time, religious tolerance became an integral part of Kashmīr civilization and the most prominent feature of Kashmīri history. People of different religions came together in Firdaus-e-bariz ${ }^{8}$ to live in unity and breathe in the atmosphere of unity and solidarity. It seems that after the spread of Islām in the medieval times, religious tolerance, literature, economy, clothing, architecture, food and drink habits, fine arts, architecture, etc., are typical examples of tolerance and interconnectedness in every field and level.

Although Süfis services to the spread of Islām and the evolution of Islāmic civilization in Kashmìr are unparalleled, historians have always praised the services of Muslim Sultans (Kings), as the Sultans of Kashmir have always been fond of the Șüfis, Dr. Aijaz Farooq said in an article reviewing the services of both Șüfis and Sultans, he writes it is challenging to determine whose efforts in both classes are more effective in this regard. At the same time, the efforts and role of Șüfis, Shaykhs, and Ulama [religious scholars] are not only more significant but also crucial, at the same time the efforts and intense struggle of the Sultans of Islām and the patronage of the efforts of preaching Islam and their cooperation is also no less important. It would be fair to say that the two classes, with the cooperation and guidance of each other, did a great job of introducing Islām in Kashmīr and revolutionizing the political, social, cultural, and religious life of the people of Kashmir that by the end of the fifteenth century CE, ninety-five percent of the people of Kashmìr had converted to Islām and enlightened their lives with the light of Islām. ${ }^{29}$

\section{Conclusion}

From time immemorial, at different times in the history of Kashmìr, the civilizations and cultures of different nations have gone through stages of rising and fall. For the first time in the history of Kashmīr, Rishis ${ }^{30}$ and Sannyasis ${ }^{31}$ camped and laid the foundation of their civilization in their own way in the BC era. Then, with the arrival of the Aryans, a new civilization overcame the already existing civilization and culture in mutual mixing, a

\footnotetext{
27 Ashraf Zaffar, Sayed, Sayyid Mir 'Alì Hamadani, Sheikh Muhammad Uthmān and Sons, Srinagar, n.d.

28 Used as similitude for Kashmīr, meaning the highest heaven.

${ }^{29}$ Akram, Dr Aijaz Farooq, Kashmìr: Ishāt wa Farügi Isläm mein Süfìyya wa Salateen Ki Masāī, n.d., p. 240.

30 The word "Rishi" is specifically derived from Sanskrit and Indian traditions, although some medieval scholars of Islām have stated that it is derived from the Persian word "Raish" or" Rish," which refers to a bird's feathers or wings. One such example is a Baba Dawūd Mishkātī, who gives a complicated and twisted explanation. A bird without feathers has little command over its own movements and is completely reliant on the wind. And similar is the circumstance with a Rishi; he is cut off from the rest of the world and lives alone, beaten by fate. This and similar interpretations, on the other hand, have failed to convince the average Kashmīi Muslim, who, for the most part, supports the Sanskrit derivation and uses it interchangeably with his Hindu counterparts as a synonym for a sage. Actually, many Kashmīris do not connect the word with any particular order of Șüfis, instead using it to refer to any Șüfi saint.

31 Sannyasis are the Brahmins who have 'renunciated' all materials aspects of life only to gain truth.
} 
new civilization came into being. In the same way, with time, different nations settled here and paved the way for their religions and their own culture, which included Hindu and Buddhist nations. Fourteenth-century AD, the spread of Islām in Kashmīr began to spread rapidly in Kashmīr when Sǘfis from central Asia and Irān came to Kashmìr. After visiting Kashmīr, the Șüfis along with preaching Islām, came here to acquaint the people with social principles and social laws and to build a united society based on Islāmic society. Süfis and preachers came to Kashmīr and introduced to the Kashmīri people the Islāmic social system, which later took the form of an organized civilization and further matured its culture in other civilizations of the world in the name of a universal civilization. This civilization also had the trait of universal Islāmic civilization, but it also had its own character of Kashmīìiyat. 